\title{
Waves and Reverse Waves: \\ Turkey Democratization After the Coup of 1960
}

\section{Fathur Rizki}

Istanbul Sabahattin Zaim University, Turkey

fathurrizki336@gmail.com

\begin{abstract}
As the country that has been experiencing several changes of governmental system, especially after the coup of 1960, made Turkey as an attractive country to look at how they implement democracy. Democracy, which is the most widely used system in the world, has ups and downs in its application especially within Turkey that has long been ruled under the monarchy of Ottoman empire and republic party system, that considered as authoritarian before it leads to the coup of military. These cases refer to the development of democratization's implementation within the country, and this paper will discuss how the waves and reverse waves of Turkey's democratization in the context of political parties' participation in Turkish state's political stage, after the military coup in 1960 by implementing the theory of world's democratization waves by Samuel P. Huntington. This paper also aims to analyze the development of Turkey democratization by observing several events that happened started after the military coup in 1960 and the rest until the it comes to contemporary issues by the rise of AKP party in 2002.
\end{abstract}

Keyword: Democratization, Political Party, Waves and Reverse waves. 


\section{Introduction}

Before going further to the step how the democratization falls into the waves and reverse waves in Turkey after the military coup in 1960, there must be a definition that explain the basic meaning of democratization itself. It is coming from the basic democracy which defined as about the institutionalization of people's power (Welzel, C., Haerpfer, C.W., Bernhagen, P., and Inglehart, R.F, 2009). The government by people, for people and every single thing related with behalf of society either their life in private or their right in politics. If we talk about democracy, there might be certain point to be focused on. Democracy has a huge definition because it has a basic on civic freedom. Society has a right toward their lives, both in determining their property and their political right. Democracy could be free elections because it one of the symbol people are able to utilize their political right. It also includes freedom of speech, and the protection of human right (Mc Laren, L., and Cop, Burak, 2011). Democracy has developed from time to time to moderate people's right and freedom. And democratization is the process by which this happens just like what Christian W. Haerpfer said in his book "Democratization". So, to define it, democratization is the process how democracy applied in the society. Progress that might have the success and failure in his way of implementation within the society. Just like what the Huntington classified the democratization into waves and reverse waves, then divided it into several steps of waves and its reverse of democratization in the history of the world (Huntington, S.P., 1991). These waves and reverse waves in democratization also suited with the system of democratization in the country. It because the state actor acted in the different way, based on the ideology and under the behalf of the leader. It leads to the diversity of the system of the government and create multiply ideology during the reign.

As the country with the republican system and aimed to apply democracy as the ideology of the state, Turkey had fell into these steps of democratization for several times. Especially after the coup of 1960 where the military revolution limits the right of the people either in politics or in social. Limiting the right of the people to participate in the stage of politics and banning political parties in the election became one of the tools to offend democracy. This coup remained a serious wound for Turkish democracy which impacted the restrained policies conditions made by civilian politician. In some case, media and university had no power and legitimacy to voice the critics over the government. These cases become the tools how the freedom of expression toward the politics come to questioned while the coup ran governmental arena. After the emerging of moderate parties and generals, 


\section{Fathur Rizki \\ Waves and Reverse Waves: \\ Turkey Democratization After the Coup of 1960.}

who promised to bring democracy to the civilian hands through new constitution, Turkey entered steps of its waves of democracy. Where new parties based on the behalf of society are emerged. This transition from up to down and contrary of democracy, could be drawn by the concept of waves and reverse waves of democratization by Huntington (Welzel, C., Haerpfer, C.W., Bernhagen, P., and Inglehart, R.F). The implementation of Huntington's theory about the waves and reverse waves of democracy in Turkish republic would be discussed in this article, which could be drawn as the exact sample of how the development of democratization in the world implemented into democratization within the country. It would be divided into several steps started after the coup of military in 1960 until the contemporary cases of AKP party, where the mass democratization come into question for several group of people.

\section{The Coup of 1960: The first reverse waves of Turkey democratization}

From 1950 until the launch of the coup 10 years later, Turkey has experienced a democratic crisis that has brought people's lives further away from prosperous. The economic conflict which led to inflation, dragged the state to put people into force to help economic development so that they could survive between crisis conditions. This was later used as an excuse by the military to do a coup against the government. Where the civil government is considered irresponsible and has failed to hold power and torment the people. This is the reason the military forces take over and launch a coup in Turkish state government building. The implementation of this coup was a long plan of action that had been carefully arranged and planned by the military elite. The movement, led by Colonel Gürsel, has two ways of launching the movement. There are two methods were used by the military for this coup. The first was to occupy the capital city as the center of government. This is because the capital is the core of the state government, where most of the state's activities are carried out in it. By occupying the capital city, coup could launch and the influence over other regions are easier to achieve with maintaining the effectiveness. Occupying the capital city certainly has very high consequences, where state security must also have a tighter level of guarding than others. This might have a consideration for the military to launch an attack. By considering this issue, it leads to the second actions which is finding an important figure respected by the army. Colonel Gürsel, who was one of the top military officers with the character and stature respected by other military forces, finally elected as a leader in the coup movement in 1960 which was the forerunner of the democratization turmoil 
on the participation of political parties in election especially by the establishment of NUC.

\section{NUC (National Union Committee)}

Cemal Gürsel as the leader, formed a committee called the National Unity Committee (Milli Birlik Komitesi) to take control of the Turkish government under the military force. NUC considered as a committee that has fully control over the country's political policies (Erik J, Zürcher, 2017). Gürsel himself was also a leader with a high position when the coup was successful. He served as head of state, prime minister and minister of defense at the same time where Mustafa Kemal "Atatürk" never served as such. With such a position, Gürsel has high authority in state policies including arranging a new constitution to grant special rights to the NUC. The temporary constitution was enacted so that the NUC has the right to regulate state policies and all matters that come out of and for the state must go through the NUC approval. This is done to anticipate that these policies are out of the military's vision for state security.

As a committee that holds the way of governing the Turkish state, it is not surprising that the NUC has a strong military force with several leader figures with various visions to build the Turkish state. This was the cause triggered a split and clash of ideology within the NUC itself. NUC consists of various high-ranking characters in the committee. Where there were divided into those who are classified as moderate, stay away from being authoritarian towards the people. This group is led by Cemal Gürsel and tends not to go too far to intervene in people's freedom. This group is inversely proportional to some of the radical groups in which Colonel Alpaslan Türkeş was one of the figures of it. He Türkeş proposed to form a body for the Union of Turkish Aspirations and Culture (Türkiye Ülkü ve Kultur Birliği) in October 1960. Where this agency would later take over the functions of several ministers such as the minister of education and religious affair, then also the freedom of the mass press. This was considered too authoritarian and limited the rights of the Turkish people, several high-ranking KPN officials, especially Cemal Gürsel, who ultimately did not approve of the formation of the agency. The radical ideologies that existed among several groups were finally disbanded and expelled from the NUC by Gürsel in November 1960. Some generals who had a desire to rule authoritatively were eventually expelled from the NUC by Gürsel, including Colonel Alpaslan Türkeş, especially after inspiring the plan to form a Turkish Culture and Ideals Union body which was considered too far in interfering in the rights and freedoms of the people 


\section{Fathur Rizki \\ "Waves and Reverse Waves" \\ Turkey democratization (free election) after the coup of 1960.}

\section{The Coup's operation}

Back at the time how the coup took over the government. At the end of the 1950 decade, the Democrat Party which was in control of the state at that time became fully authoritarian. The government choose to close all opposition parties against party policy. This is where the rebellion occurred by several parties which led to the coup and revolution in 1960. The authoritarian nature which led by the civilian parties was opposed by many sectors. It caused many disputes and crisis thus bringing the military to move and seizing power. This is related to what Erik J Zürcher said in his book "Turkey: A modern history" that the coup that would be carried out in 1960 was a long plan of generals, colonels and military elites for a long time. This is because the Turkish government continues to fall in a long up and down in the welfare of the country until there are many conflicts, whether they come from internal or external disputes with other countries. Inflation, the food crisis and the welfare of the people have become the main problems that have become the fulcrum for launching revolutions and military coups.

However, even some colonels in military were moderate and not very strict with authoritarian type while governing the country, it still considers as decreasing democratization of political parties' participation. Because certain groups within the military were often interfere in politics. It is signed by the warning that made by the Armed Forces Union (Silahli Kuvvetler Birliği) toward civilian politicians to not return to the politics for certain time of period (Erik J, Zürcher, 2017). This force emerged after the policies of some of the top military forces to prevent interfered action from the junior army. NUC as the authority institution in that time, was also legitimated to execute the laws (Varol O. Ozan, 2012). This action resulted by NUC, where the result of the internal debate within the authority did not publish to the public made lack of transparency over the policies (Varol O. Ozan, 2012). This might lead to misinterpretation by people over the government (NUC), where the stage of politics seems under the hold of military. After the emergence of parties during the year of 1960 to the rest, there still policies that made democracy did not fully applied in Turkey. It showed by closure of 25 parties in the last 45 years (Mc Laren, L., and Cop, 2011). It is considered as a big amount for the country with the aim of democracy transition. This is how the first reverse waves in Turkey democratization happened after the military coup in 1960. 


\section{The First wave: Back to democracy}

Turkey's first wave of democratization after the coup was the policy of moderate generals in the military to return to democracy (Erik J, Zürcher, 2017). Where the new constitution is established by counter balancing the position of the national assembly with several institutions in order to avoid monopolistic or authoritarian characteristics as has happened (Erik J, Zürcher, 2017). Several other policies have also begun to look a little more moderate, the mass media have again been granted autonomous rights without any intervention and restraint from the government. Universities also gain the autonomous as well, where the right of freedom to argue is guaranteed. Unlike at the beginning of the coup, where some professors were prohibited from doing activities on campuses.

The coup exploded with the aim to end the reign of Democratic party after the run the politics in Turkey for several years (Asli Daldal, 2004). So in the other word, military intervention into politics is to build the democratic rules within the society but with unconstitutional way (Ümit cizre-sakallioğlu, 1994). This way of intervention, even has considered as illegal, but in some point, it drives political stage in Turkey to be more liberal after 1961 (Ümit cizre-sakallioğlu, 1994). So, this first wave of democracy in Turkey is a must for military to establish it among the society. The first reverse wave of democratization within Turkey is a process before establishing liberal democracy in political arena within the region. Military is also backed up by several groups consisted of intelligentsia and civilian/military bureaucracy to take over the government (Ümit cizre-sakallioğlu, 1994). So by this back up, military must return democracy to the civilian politician to run the politics in Turkey by establishing the new constitution in 1961.

Here, new political parties are emerged followed by the people's participation in supporting them. The party that based on behalf of people and their ideology is Worker's party of Turkey (Türkiye İşçi Partisi) (Erik J, Zürcher, 2017). Where the workers are showing up their voice and right through political stage. This is showed that political activity not as strict as before when the early time of coup in 1960. The election in 1961 also described as free and fair, where the parties which have the ideology of democracy (Erik J, Zürcher, 2017). dominated election. This was a significant step for the first wave of democratization in Turkey after the coup. Where the right of the people in politics are no longer under the restraint and more moderate based on the new constitution. This was the break point for the good step in 


\section{Fathur Rizki \\ "Waves and Reverse Waves" \\ Turkey democratization (free election) after the coup of 1960.}

democratizing Turkish political stage especially the competition in the election. Turkey has a multi-party system until the election in 1977 before the coup once again took over the government in 1980, which became the second ebb of democratization in Turkey.

\section{The Coup in 1980: Second Reverse waves of Turkish democratization.}

The next ebb occurred in the freedom of Turkish political parties to contest in general elections when another coup broke out in 1980. The military coup is considered to be more severe than the one that happened in 1961 (George S. Harris, 2011) because there are several policies that are considered to contain authoritarian values for political rights more than in 1960. Among them are the closure of all political activities, as well as the detention of several politicians, indicating that the country's political activities are in the second ebb. This ebb brought political activities to a halt in Turkey, and the elections were also been under restraint for several years. The last election was in 1977 where there were still several parties that took part in the election contest (multi-party system). The ebb of Turkey's democratization during the military coup, whether it was in 1960 or 1980, both had an authoritarian nature where it was certain that the state was only held under military control. In 1980, after the coup took over the government, the appointment of Kenan Evren as prime minister of state by the military gave him authoritarian rights to regulate policies based on the will and benefits of the military. This was marked by the elaboration of the new system, laws and constitutions with several policies under military control and under the approvement of Kenan Evren as the leader.

After took over the government, National security council which represent by the general Kenan Evren has establish the new commandment that regarded to the civilian. It is the new form of constitution in 1982 where the powers of the government are in the hands of civilian. But while establishing it, General Kenan Evran has emerged certain policies to cooling-off political activities from civilian politician, cooling-off the civilian political parties is the way that choosen by Kenan Evren to handle the situation within the country with the aim to establish the new concept of democracy. This step of suspension of political parties within the country (Turkey) seems a forceful power to hush the political competition. This is a highlight that the opposition finds it difficult to find a place to speak out on the political stage. Like Süleyman Demirel and Bülent Ecevit, who refused to collaborate with the 
generals, which ultimately led to the prohibition of the two political figures from entering the world of politics. Their parties were also banned from political activities (George S. Harris, 2011). Even Bülent Ecevit, who was once the head of the party that made by Mustafa Kemal Atatürk, was treated the same as any other opposition. Whereas Mustafa Kemal Atatürk is considered a role model of leader for the state by the military.

Specialization that also given to Kenan Evren where he mandated as the chief of the state and specialized by the right that he could veto the constitution amendment (George S. Harris, 2011). This high position that given to the single power of the chairman of the state could challenge the stability of democracy within the country. The legitimacy of military intervention toward the politics and emerging National Security council as the legitimate institution in deciding national policies are also the tools of how civilian as the major actor in democracy are limited their right to participate in political arena. The takeover action by the actor of the coup then resulted the constitution that given the military a new right in interfering political stage is considered as over action by the state. This led the country into turmoil if the civilian politicians are trying to enter the politics and military are avoid to cooperate. Authoritarian regime will be emerged and people could begin to suffer as the result of non-democratic action, whether it comes from NUC or Kenan Evren as the power holder in that time. This reduces freedom of expression in politics for those who oppose the military generals' policies which lately transform into authoritarian. This is where the reverse waves for politicians trying to uphold democracy in Turkey. The military coup with an authoritarian reign has seen Turkey's democratization experience a second ebb in terms of political party participation.

\section{Election in 1983: The second wave of democratization}

In 1983, when general elections took place that year, several new parties began to emerge with various ideologies. This is again a fresh air for freedom of speech, at least for politicians other than the two previous public figures (Süleyman Demirel and Bülent Ecevit) to express their own ideas and perspectives for politics. Although the military commanders' intervention in election which they limit the political parties to take part in the election contest is just only 3 parties, this has become a wave for freedom of the people to elect their leader based on their own choice. During the election, there were still several calls from Kenan Evren not to vote for the ANAP (Anavatan Partisi) party or motherland party represented by Turgut Özal in the 1983 election, but the people's votes refused until it resulted in the victory of Özal. While Kenan Evren's party (MDP, or Miliyetci Democratik Partisi) or it can also be interpreted as a nationalist democratic party, had the lowest rank in the election. This indicates that people's 
trust in military power in leading the country is decreasing and rise of mistrust over them, especially after the coup in the previous 3 years. Public's rejection of Evren's call not to vote for Turgut Özal is one example of Turkey's democratization rising from the dark days of the coup. The wave for Turkish democracy re-opened after the authoritarian military era was passed. As the new government came under Turgut Özal's control, the transition from an authoritarian military era to a more democratic era could be carried out well. This was the tidal wave of Turkey's democratization in a political contest after the coup in 1980.

\section{The Third Reverse waves: AKP's domination}

In this phase, there are several debates says that Turkey's democratization is experiencing a receding period. Because since 2002 until now, the dominance of the parliament has been controlled by one party, the AKP party (Adalet ve kalk1nma partisi). This phase began in 2002, when only two political parties were able to get seats in parliament since 1954 (Omer Çaha, 2003). Up until now, the AKP's domination was seen as a one-party system, where dominance has always been held by the party led by the current Turkish president, Recep Tayyeb Erdoğan. This is considered by the opposition to be authoritarian, because the representatives from the AKP party get more seats in the parliament which led to the dominance policies on behalf of the party.

The AKP has ruled the Turkish state close to its two-decade term of leadership. Where a conservative ideology applied in the Turkish state without scratching the secular values of the Turkish state itself. However, the popularity of this party is increasingly faded, because several policies that are considered by the public are increasingly leading to a crisis of democracy in Turkey or in the other word, going to be authoritarian (Ziya Önis, 2015). Öniş also said that Erdoğan's administration had turned slightly authoritarian (Ziya Önis, 2015), where space for the opposition is narrowed so that the opposition moves less to voice resistance. This is considered to be the ebb of Turkey's democratization in terms of political rights. However, the focus of the study in this article is the participation of political parties in elections, where parties can still get the opportunity to participate on the stage of political competition. When viewed from the historical traces of the 
presidential election in Turkey, from 2002 to the present, Turkey is still running a multi-party system, where several parties with various ideologies can compete on the political stage. Even though AKP will win the election and majority of the seat in the parliament. That's why this ebb I put it on debate, because even AKP considered restraint the opposition, but there still parties are joining the election during the reign which draws the democracy in term of free election.

\section{Third Wave: AKP loss in regional elections}

The third tidal wave was when the representative votes from the CHP party won in several cities in Turkey, including the two biggest cities of population, Istanbul and Ankara. People's trust has decreased especially after the economic crisis that Turkey faces in contemporary. The down of Turkish currency, Turkish Lira during the current time made the support for the AKP reign for the next election is in doubt. This is one of the reasons why AKP's domination did not go well in Istanbul and Ankara. New leader of Istanbul, Ekrem İmamoğlu seems has a good capability in maintaining the city with the biggest population in the country. Although AKP held a regional re-election for Istanbul, the AKP still lost and Ekrem Imamoğlu became governor of Istanbul from the CHP party. This may be a consideration for the upcoming presidential elections, because perhaps a third wave of democratization of Turkey will occur and the dominance of the AKP party will decline. This is what is considered a tidal wave for Turkey's democratization, because there will be competition in the upcoming Turkish elections in 2023, either AKP still remain in the power or the opposition gained more votes to end the domination.

\section{Conclusion}

Seeing the development of democratic elections in Turkey by applying the wave and reverse waves implementation of world democratization by Samuel Huntington, can classify democratization in Turkey has 3 waves after the military coup in 1960. The revolution and several changes in the contents of the constitution that benefited the military were considered to be the first ebb and wave of Turkey's democratization at the time. This reverse wave occurred because some political rights were limited by the military, and policies made for the state had to be under military command at that time. While the wave of democratization is when moderate military generals like General Gursel, choose to return Turkey to the path of democracy. This (democracy) went smoothly and Turkey is under multi-party system until finally arrived in 1980, when the second military coup erupted, and it even arguably more severe. This year, political activity has been shut down and parties are closed. Several political figures who 
"Waves and Reverse Waves"

Turkey democratization (free election) after the coup of 1960.

refuse to incorporate are also sanctioned to prohibit them from joining the world of politics. This is what made democratization in Turkey experiencing the second reverse wave until it finally back to wave again by several events in 1983. Political activity was re-opened, parties were joined the contest in election and military back-up parties has a low vote compared to the Özal's party who wins the elections. The third phase occurred in the 2002 elections where the AKP received a majority vote to occupy the government building competing with the CHP. The dominance of the AKP from the 2002 elections until now has made Turkey seen as a country with a one-party system, especially since there are several policies that are towards authoritarianism. In this way, democratization of political party in competing in the stage of election once again come into the ebb. It has made some people choose to criticize the government of the AKP and turn to the CHP party. It marked by the victory of the CHP party in the regional election in Turkey, where Istanbul and Ankara were won by the CHP party as the holders of power. This case could drive Turkish people to argue that Turkey will face the third wave of democratization, if AKP loss it's voters and end their domination in the next presidential election. This is how the waves and reverse waves of Turkey's democratization in terms of general election and participation on the political scene been divided into 3 steps of waves and reverse waves by implementing steps of world democratization brought by Samuel P Huntington.

\section{Bibliography}

Welzel, C., Haerpfer, C.W., Bernhagen, P., and Inglehart, R.F, Democratization. Oxford University Express, 2009.

Huntington, S.P., (1991) Democratization's third wave. Journal of Democracy, Volume 2, Number 2, Spring 1991, pp. 12-34. doi:

https://doi.org/10.1353/jod.1991.0016

Mc Laren, L., and Cop, Burak (2011). The failure of democracy in Turkey: A comparative politics. Cambridge University Press, Vol. 46, No. 4, pp. 485-516. doi: https://www.jstor.org/stable/44482209

Erik J, Zürcher., Turkey: A modern history. Fourth edition: I.B Tauris \& Co. Ltd, 2017.

George S. Harris (2011) Military Coups and Turkish Democracy, 1960-1980, Turkish Studies, 12:2, 203-213, doi: 10.1080/14683849.2011.573181

Omer Çaha, Turkish election of November 2002 and the rise of moderate political islam (2003). Alternatives: Turkish Journal of International Relations, Vol. 2, Number 3, Fall 2003.

Ziya Önis, (2015) Monopolising the Centre: The AKP and the Uncertain Path of Turkish Democracy, The International Spectator, 50:2, 22-41, doi: $\underline{10.1080 / 03932729.2015 .1015335}$ 
Joseph S. Szyliowicz, The Turkish Elections: 1965, Middle East Journal , Autumn, 1966, Vol. 20, No. 4 (Autumn, 1966), pp. 473-494. doi: https://www.jstor.org/stable/4324060

Doorenspleet, R,. (2000) Reassessing the Three Waves of Democratization, World Politics, Apr., 2000, Vol. 52, No. 3 (Apr., 2000), pp. 384-406. doi: https://www.jstor.org/stable/25054118

William Hale (2011) The Turkish Republic and its Army, 1923-1960, Turkish Studies, 12:2, 191-201, doi: $\underline{10.1080 / 14683849.2011 .572628}$

Yaprak Gürsoy (2012) The changing role of the military in Turkish politics: democratization through coup plots?, Democratization, 19:4, 735-760, doi: $\underline{10.1080 / 13510347.2011 .623352}$

Asli Daldal (2004) The new middle class as a progressive urban coalition: the 1960 coup d'etat in Turkey, Turkish Studies, 5:3, 75-102, DOI: 10.1080/1468384042000270335

Ümit cizre-sakallioğlu, Labour and state in Turkey Middle Eastern Studies, Oct., 1992, Vol. 28, No. 4 (Oct., 1992)

Furkan Kaya (2019) The history of military coups in Turkey, Vol. 9, No. 2, 49-56.

D. V. Zhigulskaya (2017), Turkey after the transition to a multiparty system: the coups of 1960, 1971 and 1980, DOI 10.25205/1818-7919-2017-16-10-41-46

Frank Tachau, Metin Heper (1983) The state, Politics and the Military in Turkey, Comparative Politics, Oct., 1983, Vol. 16, No. 1 (Oct., 1983), pp. 17-33.

Kemal H Karpat (1970), The Military and Politics in Turkey, 1960-64: A Socio-Cultural Analysis of a Revolution, The American Historical Review, Oct., 1970, Vol. 75, No. 6 (Oct., 1970), pp. $1654-1683$.

I. Bal \& S. Laciner (2001) The Challenge of Revolutionary Terrorism to Turkish Democracy 1960- 80, Terrorism and Political Violence, 13:4, 90-115, DOI:https://doi.org/10.1080/09546550109609701 